\section{SIMULATION ON THE CONDITIONS AFFECTING PARTIAL DISCHARGE INITIATION IN MICROBUBBLE IMMERSED IN DIELECTRIC LIQUID}

Azharudin Mukhtaruddina*, Muzamir Isaa, Mazlee Mohd Noorb, Mohd Rafi Adzmana, Baharuddin Ismaila, M. N. K. H. Rohania, Mohd Fadzil Ainc

aSchool of Electrical System Engineering, Universiti Malaysia Perlis, Kampus Pauh Putra, 02600 Arau, Perlis, Malaysia

bSchool of Materials Engineering, Universiti Malaysia Perlis, Taman Muhibbah, 02600 Jejawi, Arau, Perlis, Malaysia

cSchool of Electrical and Electronic Engineering, USM, Engineering Campus, Seberang Perai Selatan, 14300 Nibong Tebal, Penang, Malaysia
Article history

Received

6 November 2017

Received in revised form

19 June 2018

Accepted

30 June 2018

Published online

5 October 2018

*Corresponding author azhrudinm@studentmail. unimap.edu.my

\section{Graphical abstract}

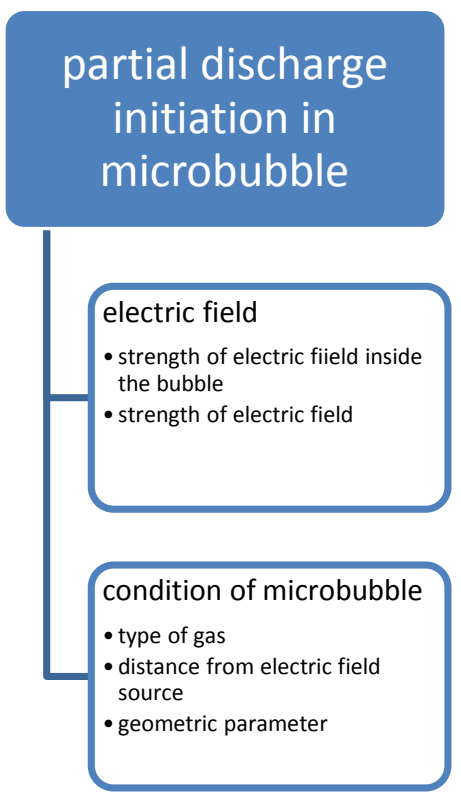

\begin{abstract}
Microbubble floating in liquid dielectric and subjected to an electric field may initiate partial discharge (PD). This paper studies the parameters that affect the initiation through a computer simulation. This study inspects how the type of gas inside the microbubble, the size of the microbubble, distance from an electric field, $\boldsymbol{E}_{\mathrm{o}}$, source and, the magnitude of source's voltage affect the start of PD. For a prolate spheroid shape, there is an important parameter called ' $c$ '. This ratio is between the radius of the microbubble polar (' $a$ ') and the radius of the equator (' $b$ '). At constant $E_{\circ}$ and $c$, different gases will initiate PD at different distances from source due to differences in a localised electric field inside the microbubble $\left(\boldsymbol{E}_{\max }\right)$. $\boldsymbol{E}_{\max }$ is one of the important factors for PD initiation. It is interesting to report that if the ' $a$ ' and ' $b$ ' values are chosen so that ' $c$ ' will be constant, changes in $\boldsymbol{E}_{\max }$ are insignificant. On the other hand, changes in ' $C$ ' will result in significant changes in $\boldsymbol{E}_{\max }$. Finally, changes in source's voltage certainly affect the $\boldsymbol{E}_{\max }$.
\end{abstract}

Keywords: Partial discharge, simulation, dielectric liquid, transformer, microbubble

\begin{abstract}
Abstrak
Buih mikro di dalam dielektrik cecair mungkin akan menghasilkan discaj separa (DS) apabila dikenakan medan elektrik. Kertas ini membincangkan parameter yang mempengaruhi DS melalui simulasi computer. Perbincangan dibuat bagi melihat bagaimana jenis gas di dalam buih, saiz buih, jarak dari punca medan elektrik, $\mathbf{E}_{\mathbf{o}}$, magnitud sumber voltan mempengaruhi permulaan DS. Bagi bentuk 'prolate spheroid, terdapat satu parameter penting yang dipanggil ' $c$ '. Parameter ini merupakan nisbah antara radius antara kutub dan radius antara ekuator sferoid berkenaan. Pada $E_{\circ}$ dan $C$ yang malar, jenis gas mempengaruhi permulaan DS pada jarak yang berbeza akibat perbezaan dalam medan elektrik setempat $\boldsymbol{E}_{\max }$. $\boldsymbol{E}_{\max }$ merupakan salah satu faktor penting dalam permulaan DS. Adalah penting untuk diutarakan bahawa jika nilai-nilai ' $a$ ' dan ' $b$ ' dipilih supaya ' $c$ ' adalah malar, perubahan dalam $\boldsymbol{E}_{\max }$ adalah kecil. Manakala perubahan ' $C$ ' akan mengakibatkan perubahan besar dalam $\boldsymbol{E}_{\max }$. Akhirnya didapati perubahan dalam voltan sumber menyebabkan perubahan nyata dalam $\boldsymbol{E}_{\max }$.
\end{abstract}

Kata kunci: Discaj separa, simulasi, dielektrik cecair, alat ubah, buih mikro 


\subsection{INTRODUCTION}

Partial discharge (PD) in dielectric liquid has been an active research due to its importance in determining the condition of insulation. In addition, PD also contributes to the degradation of insulation quality [1]. This phenomenon takes place due to several factors. For example, PD can be initiated due to microbubble, small floating material or impurity in the dielectric liquid. This paper will focus on PD due to microbubble. In fact, the presence of microbubble is essential in explaining the existence of PD in liquid [2], [3], [4]. The presence of bubble is the cornerstone of streamer theory that explains PD. Streamer theory has become more dominant in recent years [5]. Under this theory, the PD is actually the breakdown of the elongated gas bubble due to cumulative collisionionisation processes.

By definition, PD refers to a phenomenon where insulation is partially bridged electrically [6],[7]. This is in-line with the above explanation about the breakdown in a gaseous bubble. Regarding the collision-ionisation process in the bubble, two factors come into play: the presence of free electrons and adequately high electric field inside a gaseous microbubble, $\boldsymbol{E}$ [8], [9], [10], [11]. If $\boldsymbol{E}$ is larger than the breakdown of the gas residing in the bubble, $\boldsymbol{E}_{\mathbf{b}}, \mathrm{PD}$ could be initiated. The value of $\boldsymbol{E}$, on the other hand, is affected by several conditions. Some of the conditions are going to be studied in this research.

In this study, only $\boldsymbol{E}$ would be considered as an enabling factor for PD. It is assumed that the numbers of electrons are adequate. The resultant $\boldsymbol{E}$ will be studied under several conditions. They are the type of gases inside the microbubble, microbubble geometric parameters, the strength of electric field source and its distance from the source itself. From the value of $\boldsymbol{E}$, it is assumed that PD would start.

Simulation on the PD initiation will usually involve two charged electrodes with a specified gap and microbubble is placed in between [11], [12]. However, for this paper, a different approach is taken. A model was developed to mimic the actual dimension in a power transformer. It means that only one charged electrode exists: the core.

The voltage of the core will be varied, while the other electrode is the grounded transformer tank. Microbubble will be placed within the space, which is filled with dielectric liquid with specified parametric values. The distance of the microbubble relative to the surface of electric field source will also be varied.

The size and geometry shape of the microbubble also are going to be varied. The geometrical parameters that will be varied are the polar-equator radius ratios as well as the shape of the bubble. Gasses that chosen to fill the microbubble are air, ethane and methane [13].

Results from the simulation should then be analysed in term of its parameters influence in enabling the initiation of PD. Understanding can give an insight into the probability of PD to initiate inside oil-filled power transformer.

\subsection{METHODOLOGY}

Microbubble is the heart of the simulation presented in this paper. It will be subjected to a different magnitude of electrical filed, filled with different gas, located at a different distance from the electric field source and its geometric parameters are varied.

Throughout this paper, the terms microbubble and bubble are used interchangeably. Both mean the same: the minute when the bubble existed in the dielectric liquid within the power transformer.

It is important to acknowledge that distance from the pole of the microbubble to the surface of electric field source must be constant regardless of the size of the bubble. A small mathematical relationship has been developed in this paper to cater to the problem.

\subsection{Microbubble in Dielectric Liquid}

There are several views on the formation of gaseous microbubbles in the liquid dielectric. Among others are pre-existence, joule heating, electro-chemical effect (such as PD itself), electron collision, formation at a lower temperature of the moist region and different of pressure (e.g. due to vibration) [3], [4], [14], [15], [16]. In [17] it was noted that microbubble may be naturally occurred due to the presence of dissolved gasses subjected to the electric field. Among gasses that are commonly found include hydrogen, oxygen, nitrogen, methane, ethane, carbon dioxide and carbon monoxide [18], [19].

Each gas has different physical parametric values including relative permittivity, $\varepsilon_{r}$, and electric conductivity, $\sigma$. It is a fact that $\varepsilon_{r}$ and $\sigma$ values are affected by pressure and temperature. Hence, for the purpose of this paper, pressure and temperature are made constant throughout the time taken during any period of observation.

However, it can be shown that the resultant $\boldsymbol{E}$ in microbubble is only related to $\varepsilon_{r}$. Therefore, for each gas accurate, $\varepsilon r$ will be fed into the simulation. On the other hand, the value of $\sigma$ for each of the different gases can be assumed to be in the range of $1 \mathrm{fS} / \mathrm{m}$ as specified in [20]. For air, $\sigma=0 \mathrm{~S} / \mathrm{m}$ and $\varepsilon_{r}=1$ as provided by simulation software itself.

\subsection{Microbubble in Dielectric Liquid Subjected to Electric Field}

Microbubble that is subjected to the external electric field, $E_{0}$, will experience Coulomb force that eventually deforms its original shape and affects its original position. The geometric shape of a microbubble in the presence of $\boldsymbol{E}_{\mathrm{o}}$ has been reported to be prolate spheroid [2], [17], [21]. The microbubble (shaded shape) with prolate spheroid shape is shown in Figure 1. The microbubble position is shown relative to the quarter - circular conductor at the left bottom of the figure. 


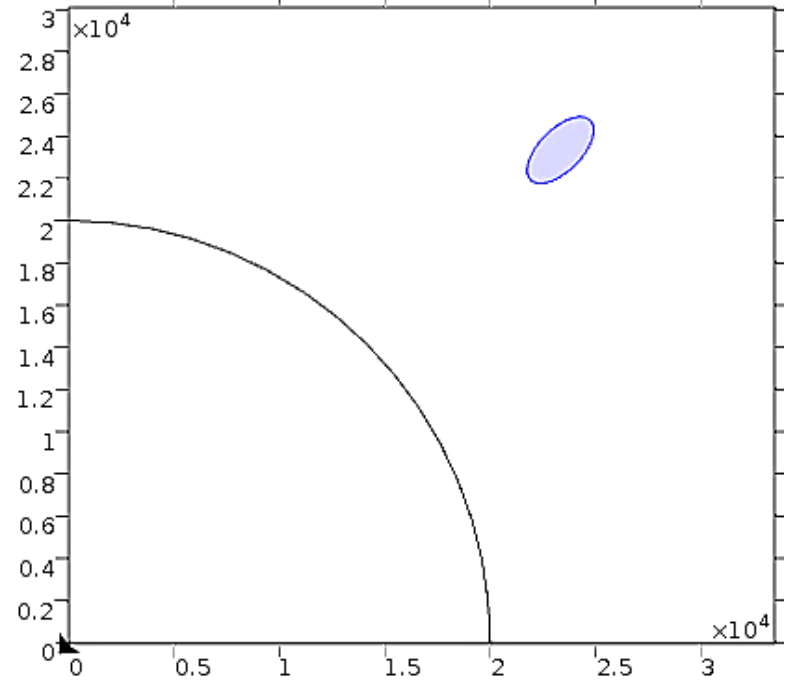

Figure 1 Prolate spheroid microbubble orientation relative to the surface of the conductor

One aspect of studies in this paper is to observe the susceptibility of PD to start for different gases. Different gas with distinct $\varepsilon$ r will result in different $\boldsymbol{E}$. For bubble, $\boldsymbol{E}$ can be described using [22]:

$$
\boldsymbol{E}=\boldsymbol{E}_{\boldsymbol{o}}\left(\frac{3 \varepsilon_{\mathrm{r}}}{2 \varepsilon_{\mathrm{r}}+1}\right)
$$

Another matter to be investigated is the effect of the size of microbubble on $\boldsymbol{E}$. It is unknown whether there is minimum or maximum bubble size for PD to take place. However, most of the articles or papers are referring to the void as microbubble [13], [23]. In fact, in [13] the size of the microbubble is stated as between $2-10 \mu \mathrm{m}$.

However, there was an experiment done using larger sizes of bubbles. Babayeva et al. reported a study where the size of the bubbles are $40-100 \mu \mathrm{m}$ [22]. For their own study, they are simulating PD for the bubble of $100-500 \mu \mathrm{m}$ in size.

In another study, bubbles sizes were divided into large (around $100 \mu \mathrm{l}$ ), medium (around $30 \mu \mathrm{l}$ ) and small (around $5 \mu$ l) [24]. Assuming that the natural shape of a small bubble in oil (before subjected to the electrical field) is spherical [25], the diameter of the bubbles would be $0.00576 \mathrm{~m}$ (5.76 mm, large), $0.00386 \mathrm{~m}$ (3.86 mm, medium) and $0.00212 \mathrm{~m}$ (2.12 $\mathrm{mm}$, small). PD was initiated in all sizes of bubbles at a different voltage, or also known as partial discharge inception voltage, PDIV. Table 1 is the tabulation of the relation between the size of bubbles and PDIV.

Table 1 Relation between the size of bubbles and PDIV [24]

\begin{tabular}{ccc}
\hline Bubble size & Size of bubble $(\mathbf{m l})$ & PDIV $(\mathbf{k V})$ \\
\hline Large & around 100 & around 40 \\
Medium & around 30 & around 56 \\
Small & around 5 & around 64 \\
\hline
\end{tabular}

Researchers in [12] reported an experimental set-up was not very much different from [24].
However, they did not report the size of the bubbles produced in the experiment [12]. Nonetheless, in their subsequent simulation designed to study the microbubble's electric field distribution in oil, the size of the bubbles were mentioned as $a=3 \mathrm{~mm}$ and $b=6 \mathrm{~mm}$. In the article, alphabets ' $a$ ' and ' $b$ ' refer to the diameters of a stretched ellipsoid, with ' $b$ ' is parallel with the electric field. In the study, it was found that for bigger a/b ratio, $\boldsymbol{E}$ inside the bubble was higher.

The motion of microbubble due to thermal conduction or any other reasons is not considered. Instead, the bubble is presumed to be stationary. The shape of the bubble is therefore assumed to be maintained [12].

The lifetime of the bubble is assumed to be long enough as if the conditions are correct, it will lead to PD commencement.

\subsection{Model Description}

Most of the properties for materials applied in this simulation have been predetermined by the software. For example, properties for air are already preloaded in the software. Hence, it is not necessary to be shown in Table 2. However, several other properties need to be defined manually. Table 2 shows the tabulation of the parameters for material properties used in modelling/simulation.

Table 2 User-defined materials properties in the simulation software

\begin{tabular}{|c|c|c|}
\hline Materials & Property (unit) & Value \\
\hline Transformer oil & $\begin{array}{l}\text { Electrical } \\
\text { conductivity, } \sigma(\mathrm{S} / \mathrm{m})\end{array}$ & $\begin{array}{l}1.52 \mathrm{pS} / \mathrm{m} \\
{[26],[27]}\end{array}$ \\
\hline Transformer oil & $\begin{array}{l}\text { Relative permittivity } \\
\text { (dielectric constant) } \\
\mu \text { (unitless) }\end{array}$ & $\begin{array}{l}2.2[28] \\
{[29]}\end{array}$ \\
\hline Ethane (gas) & $\begin{array}{l}\text { Electrical } \\
\text { conductivity, } \sigma(\mathrm{S} / \mathrm{m})\end{array}$ & $\begin{array}{l}1 \mathrm{fS} / \mathrm{m} \\
{[20]}\end{array}$ \\
\hline Ethane (gas) & $\begin{array}{l}\text { Relative permittivity } \\
\text { (dielectric constant) } \\
\mu \text { (unitless) }\end{array}$ & $\begin{array}{l}1.00138 \\
{[30]}\end{array}$ \\
\hline Methane (gas) & $\begin{array}{l}\text { Electrical } \\
\text { conductivity, } \sigma(\mathrm{S} / \mathrm{m})\end{array}$ & $1 \mathrm{fS} / \mathrm{m}[20]$ \\
\hline Methane (gas) & $\begin{array}{l}\text { Relative permittivity } \\
\text { (dielectric constant) } \\
\mu \text { (unitless) }\end{array}$ & $\begin{array}{l}1.00080 \\
{[30]}\end{array}$ \\
\hline Tank (metallic) & Side length, mm & 532 \\
\hline $\begin{array}{l}\text { Current source } \\
\text { (Copper } \\
\text { conductor) }\end{array}$ & Radius (quarter), mm & 20 \\
\hline Microbubble & $\begin{array}{l}\text { Radius (polar, } \\
\text { equatorial), } \mu \mathrm{m}\end{array}$ & Varies \\
\hline
\end{tabular}

Apart from material properties, other parameters also need to be inserted by the user. Table 3 presents the list of parameters set prior to the simulation. For Times property, the range of simulation will be from $0-0.02 \mathrm{~s}$ : one cycle of a 50 $\mathrm{Hz}$ sinusoidal electrical power supply. While the interval of the Times will be $0.001 \mathrm{~s}$. 
Table 3 User-defined components' properties in modelling software

\begin{tabular}{|c|c|c|}
\hline Components & Settings (unit, if any) & Value \\
\hline Study - Step & Times (s) & $\begin{array}{l}0,0.001 \\
0.02\end{array}$ \\
\hline Mesh & $\begin{array}{l}\text { Physics-controlled, } \\
\text { extra-fine }\end{array}$ & $\begin{array}{l}\text { Not } \\
\text { applicable }\end{array}$ \\
\hline Results - Surface & Time (s) & 0.005 \\
\hline $\begin{array}{l}\text { Results - 1D plot } \\
\text { group }\end{array}$ & Time (s) & 0.005 \\
\hline Electric current & $\begin{array}{l}\text { Out-of-plane thickness } \\
\text { (m) }\end{array}$ & 1 \\
\hline Electric current & $\begin{array}{l}\text { Reference impedance } \\
(\Omega)\end{array}$ & 50 \\
\hline $\begin{array}{l}\text { Electric current - } \\
\text { current } \\
\text { conservation }\end{array}$ & Absolute pressure (atm) & 1 \\
\hline $\begin{array}{l}\text { Electric current - } \\
\text { current } \\
\text { conservation }\end{array}$ & Temperature (K) & 300 \\
\hline
\end{tabular}

For the purpose of the simulation, only one quadrant of the 2D surface is considered for the transformer tank and the conductor. For microbubble, the full $2 \mathrm{D} 360^{\circ}$ surface is going to be used.

Within the simulation software environment, the edge of geometrical shape is called a boundary. Hence, the surface of the conductor and sides of the square are all known as boundaries. The same applies to the interface between microbubble and fluid in which it is submerged. Each boundary has a number. Any boundary can be assigned to a specific character such as electric potential, just like the surface of a conductor.

Another important concept is domain. The domain is the area enclosed by geometrical shape. For example, the area represented by a bubble is a domain. As with boundary, any domain will be assigned a number. All domains need to be assigned to appropriate materials.

Table 4 is the list of boundaries and domains and their assignment.

Table 4 Assignment of boundaries and domains

\begin{tabular}{|c|c|c|}
\hline Components & $\begin{array}{l}\text { Boundary/ } \\
\text { domain }\end{array}$ & Value, if any \\
\hline $\begin{array}{l}\text { Electric currents - } \\
\text { Electric potential }\end{array}$ & $\begin{array}{l}\text { Conductor } \\
\text { surface/ } \\
\text { boundary }\end{array}$ & $\begin{array}{l}\text { Varies V } \\
\text { V*sin }\left(2 * \text { pi }^{*} 50^{*}+\right)\end{array}$ \\
\hline $\begin{array}{l}\text { Electric currents - } \\
\text { Electric insulation }\end{array}$ & $\begin{array}{l}\text { Left and lower } \\
\text { square } \\
\text { boundaries }\end{array}$ & Nil \\
\hline $\begin{array}{l}\text { Electric currents - } \\
\text { Ground }\end{array}$ & $\begin{array}{l}\text { Right and upper } \\
\text { square } \\
\text { boundaries }\end{array}$ & Nil \\
\hline $\begin{array}{l}\text { Electric currents - } \\
\text { Current } \\
\text { conservation }\end{array}$ & All domains & Pressure - $1 \mathrm{~atm}$ \\
\hline $\begin{array}{l}\text { Electric currents - } \\
\text { Initial values }\end{array}$ & All domains & $0 \mathrm{~V}$ \\
\hline
\end{tabular}

The simulation software also has the ability to gauge result in a specific space. For this simulation, the measurement of the electric field along a line section that included the microbubble is recorded.
Figure 2 below shows the construction of the line graph. By using this facility, a 2D graph of the electric field along the line can be produced.

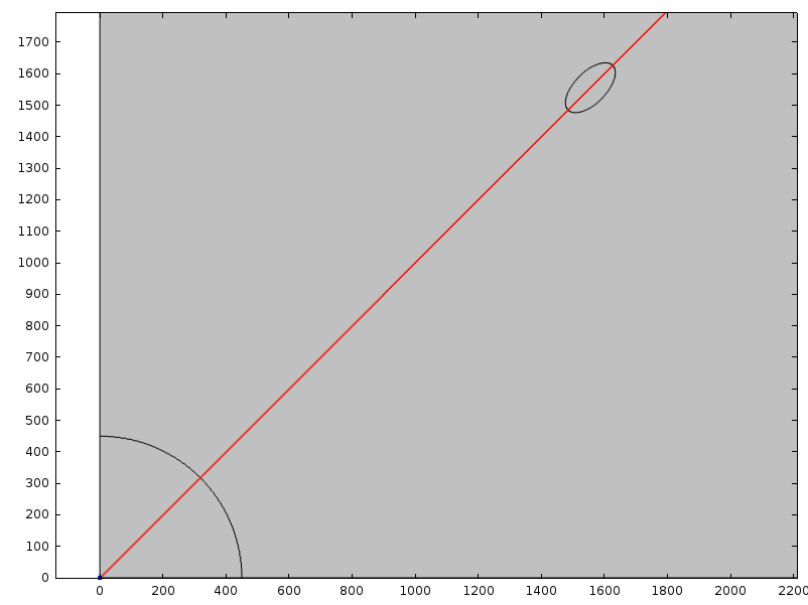

Figure $2 \mathrm{~A}$ line graph of measurement

The shape of microbubble under electric field has been reported as prolate spheroid where polar radius, $a$, is larger than the equatorial radius, $b$. If a $<b$, the resulting shape is called oblate spheroid. In [12], another parameter, $c$, is defined as a spheroid shape characteristic parameter. The parameter is defined as the following [12].

$$
c=\frac{a}{b}
$$

Where radius $a$ is along the $x$-axis and radius $b$ is along the $y$-axis. Upon inspection, the $y$-axis is found to be parallel to the electric field, $\boldsymbol{E}_{\mathrm{o}}$.

It is important to make sure that all microbubbles with different radius will be subjected to the same contour of $\boldsymbol{E}_{\text {o. }}$. Hence, the distance between the conductor surface and the conductor-facing pole tip, L, must be the same. This is regardless of the bubble size. To achieve that, a simple arithmetical relationship between $L$ and $b$ has been developed. The key is to change the mid coordinate of the bubble. Following is the relationship.

$$
x=\frac{T}{\sqrt{2}}
$$

Where, $x$ is the coordinate for the middle of microbubble $(x=y), T$ is the total length of the radius of the conductor, $r, L$ and $b$. Since $r$ and $L$ are fixed, change in $b$ will result in the new calculation of $x$. Figure 3 demonstrates the statement in graphical representation. 


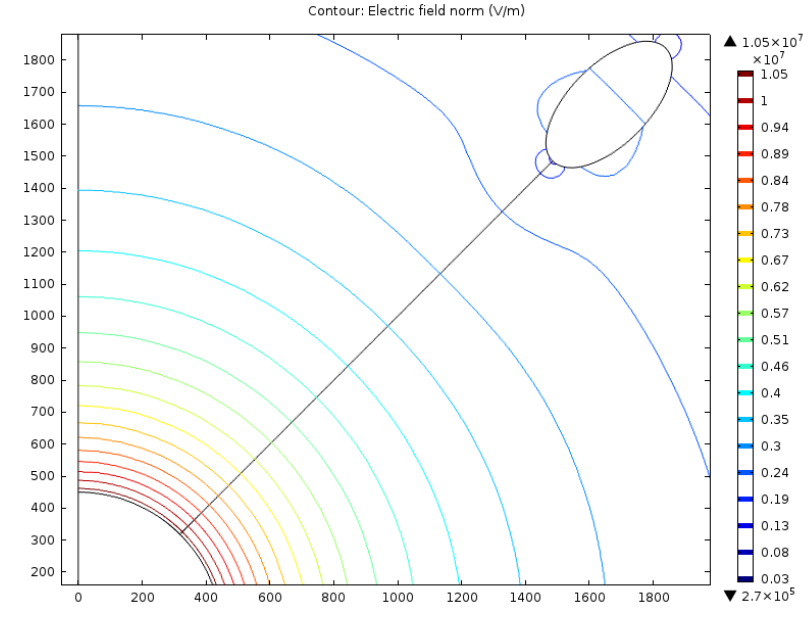

Figure 3 Contour of $\boldsymbol{E}_{\circ}$ with a fixed dimension of the bubble. Also shown is the fictitious line measuring distance from the conductor surface and the tip of the pole of a bubble

\subsection{RESULTS AND DISCUSSION}

For each simulation, the $\boldsymbol{E}_{\max }$ inside the microbubble will be noted down. This is following the convention set in [12] except for simulation that involved different gases, the rest used air-filled microbubble.

Table 5 shows the result for two out of four parameters of interest: type of gas and distance of microbubble. It can safely be concluded that the further a microbubble from the surface of the conductor, the lower $\boldsymbol{E}_{\max }$ inside it. This observation holds true for all three types of gases. Parameter $c$ is 0.5 ( $a=10 \mathrm{~mm}, \mathrm{~b}=20 \mathrm{~mm}$ ) with potential applied on the conductor is $275 \mathrm{kV}$.

Value of $\boldsymbol{E}_{\max }$ inside the microbubble for each gas is different. For example, at $9 \mathrm{~mm}, \boldsymbol{E}_{\max }$ for methane and air is $3.4595 \mathrm{kV} / \mathrm{mm}$ and 3.4699 $\mathrm{kV} / \mathrm{mm}$. The electric field strength of methane is $3.45 \times 1 \mathrm{kV} / \mathrm{mm}$ while for air it is $3 \mathrm{kV} / \mathrm{mm}$. Hence at $9 \mathrm{~mm}$, PD could be initiated for both microbubbles occupied with methane or air. Beyond this point, $\mathrm{PD}$ is not going to be initiated in a methane-filled microbubble. For air-filled microbubble, on the other hand, initiation of PD is possible up until the distance of $13 \mathrm{~mm}$.

Table 5 Measurement of $\boldsymbol{E}_{\max }$ for different gaseous microbubble with fixed geometric dimension at different distances

\begin{tabular}{cccc}
\hline Distance $(\mathbf{m m})$ & \multicolumn{3}{c}{$E_{\max }(\mathbf{k V} / \mathbf{m m})$} \\
\cline { 2 - 4 } & Ethane & Methane & Air \\
\hline 5 & 4.0080 & 4.0083 & 4.0089 \\
6 & 3.8695 & 3.8598 & 3.8603 \\
7 & 3.7140 & 3.7145 & 3.7149 \\
8 & 3.5865 & 3.5868 & 3.5873 \\
9 & 3.4592 & 3.4595 & 3.4699 \\
10 & 3.3433 & 3.3435 & 3.3441 \\
11 & 3.2330 & 3.2333 & 3.2337 \\
12 & 3.1361 & 3.1365 & 3.1368 \\
13 & 3.0411 & 3.0414 & 3.0418 \\
14 & 2.9534 & 2.9537 & 2.9540 \\
15 & 2.8686 & 2.8689 & 2.8692 \\
\hline
\end{tabular}

The reduction of $\boldsymbol{E}_{\max }$ inside a microbubble is evidently seen in Figure 4 below. The reduction can largely be explained due to the distance of microbubble to the edge of the conductor. For air it is $99.17 \%$, methane is $99.12 \%$ and ethane is $99.09 \%$.

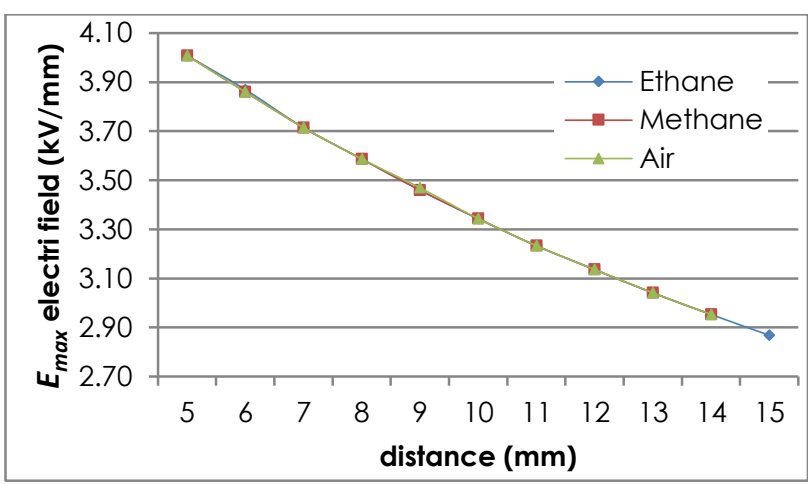

Figure 4 Value of $\boldsymbol{E}_{\max }$ for different gases at different distances

Parameter $\mathrm{c}$ can be made from a different pair of $a$ and $b$. Table 6 shows how $c=0.5$ can be made from different pairs of $a$ and $b$. It can be deduced that values of $a$ and $b$ for the same $c$ do not influence $\boldsymbol{E}_{\max }$ very much. For example, difference of $\boldsymbol{E}_{\max }$ for $\mathrm{a} / \mathrm{b}=1 / 2$ and $\mathrm{a} / \mathrm{b}=25 / 50$ is only $1.36 \%$. In fact for $a / b=1 / 2$ and $a / b=$ 20000/1000, the difference of $\boldsymbol{E}_{\max }$ is only $3.3 \%$. Statistically, the standard deviation of $\boldsymbol{E}_{\max }$ is found to be only 0.03 .

Table 6 Constant $c=0.5$ for different $a$ and $b$ pairs (arc distance $=14 \mathrm{~mm}$, electric source $275 \mathrm{kV}$ )

\begin{tabular}{cc}
\hline $\mathbf{a} / \mathbf{b}(\boldsymbol{\mu m})$ & $\boldsymbol{E}_{\max }(\mathbf{k V} / \mathbf{~ m m})$ \\
\hline $1 / 2$ & 2.95 \\
$2 / 4$ & 2.95 \\
$4 / 8$ & 2.95 \\
$5 / 10$ & 2.95 \\
$10 / 20$ & 2.95 \\
$15 / 30$ & 2.96 \\
$20 / 40$ & 2.99 \\
$25 / 50$ & 2.99 \\
$50 / 100$ & 3.00 \\
$100 / 200$ & 3.00 \\
$200 / 400$ & 3.00 \\
$500 / 1000$ & 3.00 \\
$750 / 1500$ & 3.00 \\
$1500 / 3000$ & 3.00 \\
$3000 / 6000$ & 3.02 \\
$10000 / 20000$ & 3.05 \\
\hline
\end{tabular}

Table 7 shows resultant $\boldsymbol{E}_{\max }$ for different $\mathrm{C}$. From the table, it can be seen that as $c$ is increased, so is $\boldsymbol{E}_{\text {max }}$. This is in-line with the results shown in [12]. For microbubble with $c=0.125$, the maximum $\boldsymbol{E}_{\max }$ is not enough to initiate PD. Following results in Table 6 , any combination of dimensions of microbubble that yield $c=0.125$, no $P D$ is expected to be started. 
Table 7 Value of $\boldsymbol{E}_{\max }$ for variants of $\mathrm{C}$ for spheroid-shape microbubble, (arc distance $=14 \mathrm{~mm}$, source $275 \mathrm{kV}$ )

\begin{tabular}{ccc}
\hline $\begin{array}{c}\text { Radius a }(\boldsymbol{\mu m}) / \\
\text { radius b }(\boldsymbol{\mu m})\end{array}$ & $\mathbf{C}$ & $\boldsymbol{E}_{\max }(\mathbf{k V} / \mathbf{m m})$ \\
\hline $1 / 8$ & 0.125 & 2.68 \\
$2 / 8$ & 0.25 & 2.90 \\
$3 / 8$ & 0.375 & 2.95 \\
$4 / 8$ & 0.2 & 2.95 \\
$5 / 8$ & 0.625 & 3.10 \\
$6 / 8$ & 0.75 & 3.18 \\
$7 / 8$ & 0.875 & 3.27 \\
\hline
\end{tabular}

Using data in Table 7 above, the relationship of parameter $C$ and $\boldsymbol{E}_{\max }$ can be shown in Figure 5 below. The $\mathrm{R}^{2}$ is $88.95 \%$ indicating that changes in $E_{\max }$ can be largely explained by changes in C.

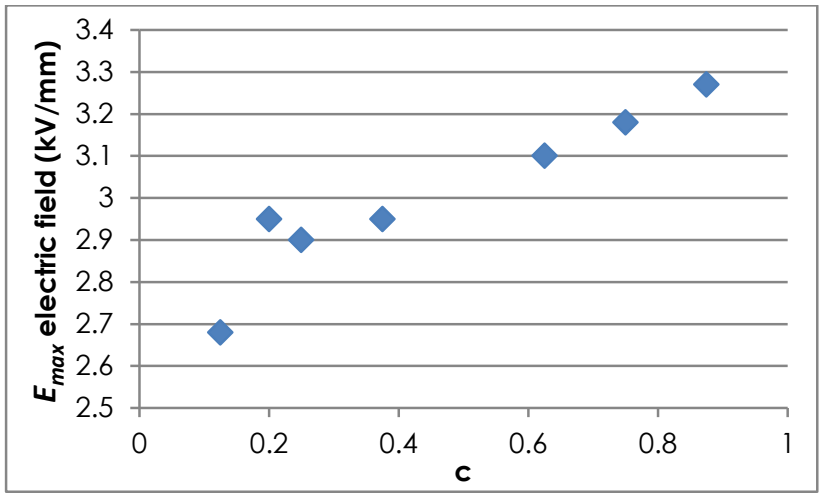

Figure 5 Relationship between parameter $\mathrm{C}$ and $\boldsymbol{E}_{\max }$

By changing the source voltage, the external electrical, $\boldsymbol{E}$, strength engulfing the microbubble is also changing. Thus, $\boldsymbol{E}_{\max }$ is also affected. Table 8 shows the result of such simulation. Change in the source's voltage magnitude caused $\boldsymbol{E}_{\max }$ to change linearly.

Table 8 Value of $\boldsymbol{E}_{\max }$ for spheroid-shape microbubble, c= $10 / 20$, subjected to a different magnitude of voltages, (arc distance $=10 \mathrm{~mm}$ )

\begin{tabular}{cc}
\hline Source voltage $(\mathbf{k V})$ & $\boldsymbol{E}_{\max }(\mathbf{k V} / \mathbf{m m})$ \\
\hline 11 & 0.13 \\
22 & 0.27 \\
33 & 0.40 \\
66 & 0.80 \\
132 & 1.61 \\
275 & 3.34 \\
500 & 6.08 \\
\hline
\end{tabular}

The fact of linear relationship can be emphasised further when the data are plotted as in Figure 6 . The linearity is so strong that the $\mathrm{R}^{2}$ is $100 \%$. The source voltages of $11,22,33,66,132,275$ and $500 \mathrm{kV}$ are based on the common utilities' distribution and transmission voltage levels found in Malaysia. However, 22 and $66 \mathrm{kV}$ are believed to be currently phased out from usage.

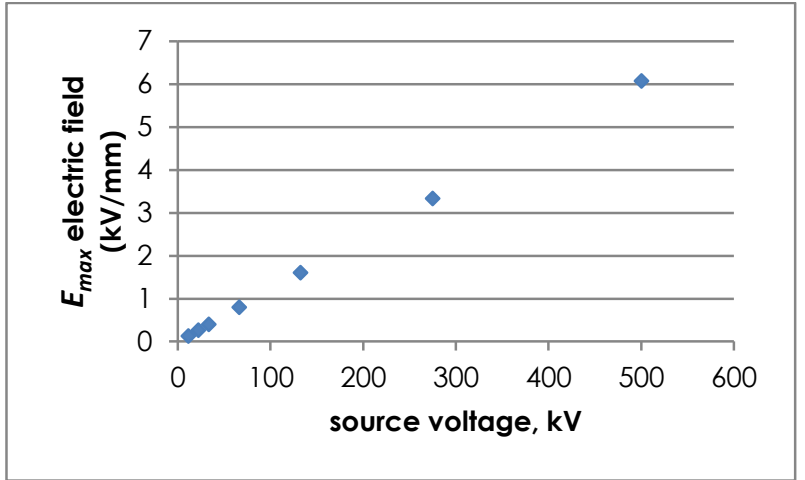

Figure 6 Relationship between the source voltage and $E_{\max }$

\subsection{CONCLUSION}

By assuming there are enough free electrons existed in the microbubble, several conditions that may contribute to PD initiation can be studied.

It is found that the $\boldsymbol{E}_{\max }$ is strongly affected by the type of gasses. This is due to the fact that $\boldsymbol{E}_{\max }$ is influenced by $\varepsilon_{r}$ for each gas.

From the study, it was found that at the same source' voltage magnitude, $\boldsymbol{E}_{\max }$ reduced significantly by the enlargement of distance.

On the other hand, increased in $\boldsymbol{E}_{\max }$ is observed for increased in $c$ and in source's voltage magnitude.

However, no significant changes can be observed in $\boldsymbol{E}_{\max }$ changes of size of microbubble for constant $\mathrm{C}$.

\section{Acknowledgement}

The author (AM) expresses gratitude to the Malaysian Ministry of Higher Education (MOHE) for assistance under MyPhD scheme.

\section{References}

[1] M. Shafiq, L. Kutt, M. Isa, M. Hashmi, M. Lehtonen. 2012. Directional Calibration of Rogowski Coil for Localization of Partial Discharges in Smart Distribution Networks. International Review of Electrical Engineering. 7(5): 5881-5890.

[2] Kolb, J. F., Joshi, R. P., Xiao, S., and Schoenbach. K. H. 2008. Streamers in Water and other Dielectric Liquids. Journal of Physics D: Applied Physics. 41 (23): 234007. DOI: doi.org/10.1088/0022-3727/41/23/ 234007.

[3] Jin, H. 2015. Dielectric Strength and Thermal Conductivity of Mineral Oil based Nanofluids. TU Delft. PhD Thesis.

DOI: doi.org/10.4233/uvid:10d18961-a23f-478e-b6e2$181 \mathrm{~d} 897 \mathrm{~d} 8541$

[4] Sun, A., Huo, C., and Zhuang, J. 2016. Formation Mechanism of Streamer Discharges in Liquids: A Review. High Voltage. 1 (2): 74-80.

DOI: doi.org/10.1049/hve.2016.0016.

[5] Wang, X. 2011. Partial Discharge Behaviours and Breakdown Mechanisms of Ester Transformer Liquids Under AC Stress. University of Manchester. PhD Thesis.

[6] _ 2000. IS/IEC 60270 (2000): High-Voltage Techniques Measurements [ETD 19: High Voltage Engineering]. New Delhi: Bureau of Indian Standards.

[7] M. N. K. H. Rohani, C. C. Yii, M. Isa, S. I. S. Hassan, A. 
Mukhtaruddin, N. A. Yusof, B. Ismail. 2015. Effect of unshielded and Shielded Rogowski Coil Sensor Performance for Partial Discharge Measurement. 2015 IEEE Student Conference on Research and Development, SCOReD 2015, Pages 21-25, 13-14 December, 2015, Kuala Lumpur, Malaysia.

DOI: $10.1109 /$ SCORED.2015.7449325.

[8] Abd Rahman, M. S. 2014. Identification of Partial Discharge Sources and Their Location Within High Voltage Transformer Windings. University of Southampton. PhD Thesis.

[9] Chakravorti, S., Dey, D. and Chatterjee, B. 2013. Recent Trends in the Condition Monitoring of Transformers: Theory, Implementation and Analysis. London: SpringerVerlag,

DOI: doi.org/10.1007/978-1-4471-5550-8.

[10] Niasar, M. G. 2012. Partial Discharge Signatures of Defects in Insulation Systems Consisting of Oil and OilImpregnated Paper. The Royal Institute of Technology: Licentiate Thesis.

[11] Chen, G., Illias, H. A. and Lewin, P. L. 2012. Partial Discharge Within a Spherical Cavity in a Dielectric Material as a Function of Cavity Size and Material Temperature. IET Science, Measurement and Technology. 6(2): 52-62.

DOI: doi.org/10.1049/iet-smt.2011.0091.

[12] Tang, J., Ma, S., Zhang, M., Liu, Z., Li, X. and Gui, Y.. 2015. Influence of Microbubbles Motion State on Partial Discharge in Transformer Oil. IEEE Transaction on Dielectrics and Electrical Insulation. 22(5): 2646-2652. DOI: doi.org/10.1 109/TDEl.2015.005028.

[13] Pompili, M. and Bartnikas, R. 2014. Gas Formation in Transient Cavities Undergoing PD Pulse Burst Discharges in Transformer Oils. IEEE Transaction on Plasma Science. 42(6): 1697-1703. DOI: doi.org/10.1109/TPS.2014.2317847.

[14] Grav, T. 2013. Mechanisms Governing the occurrence of Partial Discharges in Insulation Liquids. Norwegian University of Science and Technology. Master Thesis.

[15] Eikeset, J. 2014. Photon Activity from Partial Discharges in Liquid Dielectrics Experimental Test Setup and Measurements. Norwegian University of Science and Technology. Master Thesis.

http://hdl.handle.net/1 1250/257994.

[16] Korobeynikov, S. M., Bychkov, A. L., Ryzhkina, A. Y., Sviridenko, M. V., Darian, L. A. and Melekhov, A. V. 2013. Microbubbling in Transformer Oil due to Vibration. IEEE Transaction on Dielectrics and Electrical Insulation. 20(2): 675-677. DOI: doi.org/10.1109/TDEl.2013.6508771

[17] Marinov, I. 2013. Plasmas dans l'eau et Aux Interfaces. Université Paris Sud-Paris XI. PhD Thesis.

[18] Sun, H. C., Huang, Y. C. and Huang, C. M. 2012. A Review of Dissolved Gas Analysis in Power Transformers. Energy Procedia. 14(2012): 1220-1225
DOI: doi.org/10.1016/j.egypro.2011.12. 1079

[19] Bakar, N., Abu-Siada, A. and Islam, S. 2014. A Review of Dissolved Gas Analysis Measurement and Interpretation Techniques. IEEE Electrical Insulation Magazine. 30(3): 39-49.

DOI: doi.org/10.1 109/MEl.2014.6804740

[20] Berger, L. I. 2006. Dielectric Strength of Insulating Materials. In D.R. Lide (ed.) CRC Handbook of Chemistry and Physics. Boca Raton: Taylor and Francis. DOI: doi.org/10.1021/ja069813z.

[21] Tereshonok, D. V. 2016. Cavitation in Liquid Dielectric under Nanosecond High-Voltage Impulse. Journal of Physics D: Applied Physics. 50(1): 15603 DOI: doi.org/10.1088/1361-6463/50/1/015603.

[22] Babaeva, N. Y., Tereshonok, D. V. and Naidis, G. V. 2015. Initiation of Breakdown in Bubbles Immersed in Liquids: Pre-Existed Charges Versus Bubble Size. Journal of Physics D: Applied Physics. 48(35): 355201. DOI: doi.org/10.1088/0022-3727/48/35/355201.

[23] Drexler, P. , Cap, M., Fiala, P., Steinbaver, M., Kaska, M. and Kocis, L. 2015. Advanced Methods of UHF EM Diagnostic of Discharge Activity in High Voltage Transformers Dielectric. Progress In Electromagnetics Research Symposium Proceedings. 2448-2452.

[24] Niasar, M. G., Edin, H., Wang, X. and Clemence, R. 2011 , August. Partial Discharge Characteristics due to Air and Water Vapor Bubbles in Oil, XVII International Symposium on High Voltage Engineering.

[25] Haberman, W. L. and Morton, R. K. 1953. An Experimental Investigation of the Drag and Shape of Air Bubbles Rising in Various Liquids. Fort Delvoir: Defense Technical Information Center.

[26] Dong, M., Shen, L. P., Wang, H., Wang, H. B. and Miao, J. 2013. Investigation on the Electrical Conductivity of Transformer Oil-Based AIN Nanofluid. Journal of Nanomater. 2013: 164. DOI: doi.org/10.1155/2013/842963.

[27] Judendorfer, T., Pirker, A. and Muhr, M. 2011. June. Conductivity Measurements of Electrical Insulating Oils. 2011 IEEE International Conference on Dielectric Liquids (ICDL). 1-4. DOI: doi.org/10.1109/ICDL.2011.6015456.

[28] Badicu, L. V., Notingher, P. V., Dumitran, L. M. Tanasescu, G. and Popa, D. 2009. Measuring of the Dielectric Properties of Mineral Oil. Proceedings of 5th International Conference Metrology \& Measurement Systems. 284-289.

[29] Spohner, M. 2012. A Study of the Properties of Electrical Insulation Oils and of the Components of Natural Oils. Acta Polytechnica. 52(5).

[30] Younglove, B. A. and Ely, J. F. 1987. Thermophysical Properties of Fluids. II. Methane, Ethane, Propane, Isobutane, and Normal Butane. Journal of Physical and Chemical Reference Data. 16(4): 577-798. DOI: doi.org/10.1063/1.555785. 